\title{
Simultaneous Production of Lipids and Carotenoids by the Red Yeast Rhodotorula from Waste Glycerol Fraction and Potato Wastewater
}

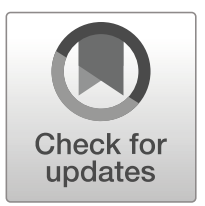

\author{
Anna M. Kot ${ }^{1}$ (D) Stanisław Błażejak ${ }^{1} \cdot$ Marek Kieliszek $^{1} \cdot$ Iwona Gientka $^{1}$ • \\ Joanna Bryś ${ }^{2}$
}

Received: 16 February 2019 / Accepted: 22 April 2019 /

Published online: 10 May 2019

(C) The Author(s) 2019

\begin{abstract}
The objective of this study was to determine the possibility of simultaneous biosynthesis of lipids and carotenoids by the Rhodotorula yeast strains in media with waste glycerol and deproteinized potato wastewater and to determine the level of pollution reduction by media. On the basis of results obtained during the yeast microcultures in the Bioscreen $\mathrm{C}$ system, it was found that potato wastewater and glycerol can be used as components of media for Rhodotorula glutinis, Rhodotorula mucilaginosa, and Rhodotorula gracilis yeast strains. The amount of glycerol added to media higher than $10 \%$ significantly decreased the growth rate of yeast. The results of yeast culture in the laboratory shaker flasks showed a possibility of simultaneous production of lipids and carotenoids by $R$. glutinis, R. mucilaginosa, and $R$. gracilis yeast strains during cultivation in media containing only waste glycerol and deproteinized potato wastewater. A higher intracellular lipid content (approximately $15 \mathrm{~g} /$ $100 \mathrm{~g}_{\text {d.w. }}$ ) was obtained for $R$. mucilaginosa and $R$. gracilis yeast biomass after cultivation in experimental media with waste glycerol and potato wastewater. In conclusion, the yeast grown in media with potato wastewater supplemented with $3 \%$ or $5 \%$ glycerol synthesized carotenoids, and their content in biomass did not exceed $230 \mu \mathrm{g} / \mathrm{g}_{\mathrm{d} . \mathrm{w}}$.
\end{abstract}

Keywords Single-cell oil $\cdot$ Microbial carotenoids $\cdot$ Red yeast $\cdot$ Industrial wastes

\section{Introduction}

The ability of yeast to synthesize large amounts of lipids became known to scientists at the beginning of the twentieth century. Microorganisms that produce more than $20 \%$ lipids in a dry

Anna M. Kot

anna_kot@sggw.pl

1 Department of Biotechnology, Microbiology and Food Evaluation, Faculty of Food Sciences,

Warsaw University of Life Sciences, ul. Nowoursynowska 159C, 02-776 Warszawa, Poland

2 Department of Chemistry, Faculty of Food Sciences, Warsaw University of Life Sciences, ul. Nowoursynowska 159C, 02-776 Warszawa, Poland 
cellular substance are called oleaginous microorganisms [1]. At present, intensive research is being conducted worldwide on the possibility of producing microbial-derived lipids on an industrial scale. This stems primarily from the fact that this process is independent of climatic conditions, requires less manual intervention, has a short production cycle, and enables the fatty acid composition to be modified by regulating culture parameters. Yeasts are excellent producers of microbial lipids because of their high content in cellular biomass. These microorganisms exhibit a rapid growth rate and low nutritional requirements, and the fatty acid composition can be modified by changing the culture conditions [2]. The group of oleaginous yeasts includes yeasts of genus Rhodotorula, which apart from lipids can also synthesize other valuable cellular components such as carotenoids [3].

Carotenoids are industrially obtained by extraction from plant materials, chemical synthesis, and biosynthesis by microorganisms. Because of the constantly growing demand, new methods and sources of obtaining these compounds are sought. Rhodotorula yeast is capable of synthesizing three types of carotenoids: $\beta$-carotene, torulene, and torularhodin. $\beta$-carotene exhibits antioxidant and provitamin A properties. In the food industry, it is mainly used as a dye and as an ingredient in dietary supplements and sun tanning creams in the pharmaceutical and cosmetic industries [3]. Torulene and torularhodin are not found in food, and their impact on the human body has not yet been studied. These compounds also exhibit strong antioxidant properties, because of which they can be used in the future in the production of food, animal feed, and cosmetics [4].

At present, the high costs of microbial biosynthesis of lipids and carotenoids by yeast limit the possibility of using these processes on an industrial scale. One of the solutions to this issue may be the use of industrial waste as components of culture media [5]. The media used for the cultivation of yeast should primarily include assimilable sources of carbon, nitrogen, minerals, sulfur, and phosphorus compounds [6]. The waste that can be a valuable source of nitrogen compounds and minerals is deproteinized potato wastewater, which is produced during the production of potato starch. In the 2016/2017 season, approximately 200,000 tons of potato starch were produced in Poland [7]. The processing of one ton of potatoes produced approximately $7 \mathrm{~m}^{3}$ of potato wastewater [8].

This waste contains $2.9-4.3 \%$ of dry matter on average, and the dry matter consists of protein $(0.93-1.57 \%)$, sugars $(0.5-0.8 \%)$, fat (emulsified with water, $0.2 \%)$, and approximately $1 \%$ of mineral compounds. Hence, the values of the chemical oxygen demand index are generally higher than $20,000 \mathrm{mg} / \mathrm{L}$. Because of the low content of reducing sugars, potato wastewater can be enriched with an additional source of carbon and energy in order to obtain a high biomass yield [9]. One such source is glycerol fraction, which is obtained from biodiesel production. It is estimated that approximately $10 \mathrm{~kg}$ of glycerol fraction is formed in the production of $100 \mathrm{~kg}$ of esters [10]. Glycerol fraction is the main by-product of the process and contains $40-70 \%$ glycerol, methanol residues (up to 14\%), free fatty acids (up to 15\%), water (2-3\%), catalyst residues, soaps, and micronutrients such as sodium, magnesium, potassium, and calcium, It depends on the production technology, the raw material used, and the degree of methanol and catalyst recovery [10-12]. The combination of deproteinized potato wastewater and glycerol fraction allows the formation of a complex microbiological medium, which is a source of macro- and micronutrients required for the growth of the yeast [5]. 
The aim of the study was to determine the possibility of simultaneous production of lipids and carotenoids by selected yeasts of the genus Rhodotorula in media containing waste glycerol fraction as a source of carbon and deproteinized potato wastewater as a source of nitrogen and minerals. In the present study, the level of pollution reduction by media was also evaluated.

\section{Materials and Methods}

\section{Biological Material}

The biological materials of this study were three yeast strains of the genus Rhodotorula. Rhodotorula glutinis LOCKR13 was obtained from the Collection of Pure Cultures of the Lodz University of Technology (Poland), while the strains R. mucilaginosa ATCC 66034 and R. gracilis ATCC 10788 were obtained from the American Collection of Pure Cultures (USA). These microorganisms were stored on yeast extract peptone dextrose (YPD) medium slants at $4{ }^{\circ} \mathrm{C}$.

\section{Waste Glycerol Fraction}

In this study, the glycerol fraction was used, which was collected during the industrial production of biodiesel from rapeseed oil (Bioagra-Oil SA, Tychy, Poland).

The content of glycerol was determined by a chemical method proposed by Milchert et al. [13], involving oxidizing activity of meta-periodic acid to hydroxyl groups in glycerol. The results were given in grams per $100 \mathrm{~g}$ of waste glycerol fraction.

The content of methanol was determined by GC-MS (Shimadzu, GCMS-QP2010S) at HP-INNOWax capillary column $(30 \mathrm{~m} \times 0.25 \mathrm{~mm} \times 0.25 \mu \mathrm{m})$ in Industrial Chemistry Research Institute in Warsaw. The results were given in grams per $100 \mathrm{~g}$ of waste glycerol fraction. The oven temperature was set at $35{ }^{\circ} \mathrm{C}(5 \mathrm{~min})$; the temperature increase rate was 10 up to $220{ }^{\circ} \mathrm{C}(17 \mathrm{~min})$. Helium was the carrier gas. The temperatures of the ion source and quadrupole were set at $200{ }^{\circ} \mathrm{C}$ and $150{ }^{\circ} \mathrm{C}$, respectively. Identification of methanol was performed on the basis of Wiley Registry of Mass Spectral Database (9th edition).

The selected minerals were determined by inductively coupled plasma atomic emission spectroscopy (ICP-AES) (Thermo iCAP 6500) in the Analytical Center of WULS, Warsaw. For this, $2 \mathrm{~mL}$ of samples were mineralized (Buchi Digestion Unit K-435) using a mixture of nitric acid $(5 \mathrm{~mL})$ and perchloric acid $(2 \mathrm{~mL})$. Mixture after mineralization was transferred to $25 \mathrm{~mL}$ flasks by $5 \mathrm{~mL}$ of hydrochloric acid and deionizer water. Measurements were made at the appropriate wavelengths for each elements - Ca 315.8, 373.6, and $422.6 \mathrm{~nm}$; K 766.4 and 769.8; $\mathrm{Mg} 279.5,280.2,285.2$, and 382.9; $\mathrm{Na} 588.9$ and 589.5; and P 177.4, 178.2, and 213.6. The results were given in grams per $100 \mathrm{~mL}$ of waste glycerol fraction.

\section{Deproteinized Potato Wastewater}

Potato wastewater was prepared in laboratory conditions according to the methodology developed on the basis of the course of individual stages of potato starch production [14]. In deproteinized potato wastewater, the content of dry substance was determined by the 
gravimetric method $\left(105^{\circ} \mathrm{C}\right.$, SML 32/250, Zatmet). The total nitrogen and protein content was determined using the Kjeldahl method (Büchi Digestion Unit K-435, Büchi Distillation Unit K-355) with a conversion factor of 6.25 [15]. The content of reducing compounds, calculated per glucose, was determined spectrophotometrically at $\lambda=550 \mathrm{~nm}$ (UV1800 spectrophotometer, Rayleigh) by using 3,5-dinitrosalicylic acid [16]. The chemical oxygen demand index was determined by the dichromate method using Hach Lange cuvette tests (LCK014) in the Water Centre of the Warsaw University of Life Sciences. The content of calcium, potassium, magnesium, sodium, and phosphorus was determined by the ICP-AES method described above.

\section{Preparation of Inoculum}

To prepare the inoculum, liquid YPD medium $(20 \mathrm{~g} / \mathrm{L}$ glucose, $20 \mathrm{~g} / \mathrm{L}$ peptone, $10 \mathrm{~g} / \mathrm{L}$ yeast extract, $\mathrm{pH} 5.0 \pm 0.1$ ) was used. This medium was inoculated with material collected from agar slants. Cultures were carried out in flasks containing $100 \mathrm{~mL}$ of the medium on a reciprocating shaker (SM-30 Control, Edmund Bühler), with a frequency of $200 \mathrm{rpm}$ at $28^{\circ} \mathrm{C}$ for $24 \mathrm{~h}$.

\section{Culture Media}

Two control media were used in the study: YPD medium and deproteinized potato wastewater. The experimental media were prepared from deproteinized potato wastewater and glycerol fraction, in which glycerol fraction was added in such an amount as to obtain an appropriate initial concentration of glycerol. To assess the growth of yeast during the cultures in the Bioscreen C system, experimental media supplemented with glycerol in doses of 30, 50, 100, 150,200 , and $250 \mathrm{~g} / \mathrm{L}$ were used. On the basis of the growth results, doses of glycerol were chosen, and these doses were used for yeast cultures on a rotary shaker in flasks.

\section{Screening of the Growth by Using the Bioscreen C System}

The culture of the Rhodotorula yeast in control and experimental media was performed using an automatic Bioscreen C system (Oy Growth Curves Ab Ltd., Finland). A total of $300 \mu \mathrm{L}$ of the inoculated medium $\left(1 \times 10^{6} \mathrm{cells} / \mathrm{mL}\right)$ was added to one microwell of the microwell plate. The cultures were carried out for $120 \mathrm{~h}$ at $28^{\circ} \mathrm{C}$ with intensive shaking. Optical density was measured at 2-h intervals by using a broadband filter $(\lambda=420-580 \mathrm{~nm})$, as recommended by the equipment manufacturer. On the basis of the obtained results, the graphs of the optical density (OD) of culture from the time of cultivation were prepared, and the time of the adaptation phase $\left(\Delta t_{\mathrm{lag}}\right)$, log phase $\left(\Delta t_{\mathrm{log}}\right)$, and the minimum and maximum OD values in the logarithmic growth phase were determined. The coefficient of specific growth rate $\left(\mu_{\max }\right)$ was also calculated using the formula: $\mu_{\max }=\left(\operatorname{lnOD}_{\max }-\operatorname{lnOD}_{\min }\right) / \Delta t_{\text {log }}$. The total increase in the OD of the culture $(\Delta \mathrm{OD})$ after $120 \mathrm{~h}$ was also determined.

\section{Experimental Culture Conditions}

Yeast cultures were grown in $500 \mathrm{~mL}$ flasks on a reciprocating shaker at $200 \mathrm{rpm}$ (SM-30 Control, Edmund Bühler) at $28^{\circ} \mathrm{C}$ for $120 \mathrm{~h}$. Media $(90 \mathrm{~mL})$ were inoculated with inoculum constituting $10 \%$ of the culture volume. 


\section{Biomass Yield}

The biomass yield was determined by the gravimetric method. For this purpose, $10 \mathrm{~mL}$ of the medium was centrifuged for $10 \mathrm{~min}$ at $6000 \times \mathrm{g}$ (Centrifuge 5804R, Eppendorf), the supernatant was decanted, and the biomass was washed twice with deionized water. The wet cell biomass was dried at $105{ }^{\circ} \mathrm{C}$ (SML 32/250, Zatmet) to obtain a constant mass. The results were calculated in grams of dry weight per liter of culture medium $\left(\mathrm{g}_{\text {d.w. }} / \mathrm{L}\right)$.

\section{Determination of Lipid Content in Yeast Biomass}

The content of intracellular lipids was determined by the modified Bligh and Dyer method. The extraction of lipids was preceded by acid hydrolysis of the dry cellular matter. For this purpose, $10 \mathrm{~mL}$ of $1 \mathrm{M} \mathrm{HCl}$ was added to $200 \mathrm{mg}$ of dry yeast biomass and incubated in a water bath at $60{ }^{\circ} \mathrm{C}$ (Memmert WNB14, Schwabach) for $2 \mathrm{~h}$. The lipids were extracted with $20 \mathrm{~mL}$ of a mixture of chloroform and methanol (1:1). To separate these phases, $5 \mathrm{~mL}$ of $20 \%$ $\mathrm{NaCl}$ was added to the solution and centrifuged $(3500 \times \mathrm{g} / 10 \mathrm{~min}$, Centrifuge 5804R, Eppendorf). The lower phase was collected, and chloroform was evaporated under nitrogen atmosphere. The lipid content in the biomass of yeast was determined gravimetrically $[17,18]$ and expressed as grams per $100 \mathrm{~g}$ of dry weight.

\section{Analysis of the Composition of Fatty Acids}

The fatty acids were esterified with a mixture of $2 \mathrm{M} \mathrm{KOH}$ in methanol. Methyl esters of fatty acids were analyzed in a gas chromatograph (TRACETM 1300, Thermo Scientific) equipped with a flame ionization detector. The separation process was carried out on a capillary column RTX-2330 $(60 \mathrm{~m} \times 0.25 \mathrm{~mm} \times 0.2 \mu \mathrm{m}$, Restek $)$. The oven temperature was set at $50{ }^{\circ} \mathrm{C}$ (3 min); the temperature increase rate was $3{ }^{\circ} \mathrm{C} / \mathrm{min}$ up to $250{ }^{\circ} \mathrm{C}(5 \mathrm{~min})$. Nitrogen $(1.6 \mathrm{~mL} / \mathrm{min})$ was the carrier gas. The temperatures of the injector and detector were set at $230{ }^{\circ} \mathrm{C}$ and $260{ }^{\circ} \mathrm{C}$, respectively. The fatty acids were identified on the basis of standard retention time (Nu-Chek Prep, Inc., USA).

\section{Determination of Carotenoid Content in Yeast Biomass}

The content of carotenoids in yeast biomass was determined by the spectrophotometric method [19]. Extraction of carotenoid pigments with a mixture of acetone $(2 \mathrm{~mL})$ and petroleum ether $(2 \mathrm{~mL})$ was preceded by disintegration of the yeast cell wall by $2 \mathrm{~mL}$ of DMSO and zirconium beads $(d=0.5 \mathrm{~mm})$. The absorbance of the colored ether fraction was measured at $\lambda=457 \mathrm{~nm}$ (UV1800 spectrophotometer, Rayleigh), and the carotenoid content was calculated using the standard curve prepared for a $\beta$-carotene solution and expressed as microgram per gram of dry substance.

\section{Identification of Carotenoids}

Carotenoids were identified by high-performance liquid chromatography coupled with a UVVis detector (Agilent 1200 Series, Palo Alto, CA, USA). The separation process of the mobile phase was carried out on a C18-2 analytical column (Bionacom, $250 \mathrm{~mm} \times 4.6 \mathrm{~mm}, 5 \mu \mathrm{m}$ ) at a wavelength of $457 \mathrm{~nm}$. The mobile phase was a mixture of acetonitrile, isopropanol, and ethyl 
acetate $(4: 4: 2 \mathrm{v} / \mathrm{v} / \mathrm{v})$, and the flow rate was set at $0.7 \mathrm{~mL} / \mathrm{min}$ (isocratically). The identification of $\beta$-carotene was based on the retention time of the standard (Sigma-Aldrich), while torulene and torularhodin were identified according to the retention times of the standards separated by thin-layer liquid chromatography (TLC) [14].

\section{Analysis of Postculture Media Composition}

The content of glycerol, nitrogen, reducing sugars, and the COD index were determined in the postculture media according to the methods described above. On the basis of the obtained results, the content of glycerol, nitrogen, and reducing sugars and the decrease in the chemical oxygen demand index were calculated.

\section{Statistical Analysis}

The results obtained from three independent experimental series were subjected to statistical analysis in the $\mathrm{R}$ program (version i386 2.15.3). The normal distribution of data was determined using the Shapiro-Wilk test, and the homogeneity of variance was determined using the Levene test. To determine the significance of differences between the average values, one-way analysis of variance (ANOVA) and Tukey's test were performed. Analyses were conducted at the significance level $\alpha=0.05$.

\section{Results and Discussion}

\section{Characteristics of Waste Glycerol Fraction and Deproteinized Potato Wastewater}

The composition of glycerol fraction (Table 1) and deproteinized potato wastewater (Table 2) was to assess their suitability as the only components of culture media for yeast of the genus Rhodotorula. The glycerol fraction mainly consisted of glycerol (60.29\%), which can be used by the Rhodotorula yeast as a source of carbon and energy [20]. According to the literature [21], the glycerol content in the glycerol fraction ranges from 40 to $70 \%$ and depends primarily on the production technology and the raw material used. For example, waste glycerol tested by Manowattan et al. [22] contained on average $56.3 \%$ glycerol, $6.1 \%$ water, $15.1 \%$ methanol, $10.8 \%$ lipid compounds, $6.1 \%$ ash, and $5.6 \%$ other pollutants. In the glycerol fraction used in this study, the methanol content was $3.30 \%$ and was a residue after the distillation process; thus, further attempts to recover would be unprofitable. In factories that are not equipped with a distillation station, the methanol content in the fraction may be as high as $14 \%$ [12]. Among the elements determined in the glycerin fraction, the highest proportion was sodium $(1.1 \%)$, which was the result of using sodium hydroxide as a catalyst in the transesterification of fatty acids in the biodiesel production. Calcium, potassium, phosphorus, and magnesium were present in trace amounts $(0.003-0.024 \%)$.

The deproteinized potato wastewater was characterized by a high content of nutrients that are necessary for the proper growth of yeast. These included primarily nitrogen compounds $(0.232 \mathrm{~g} / 100 \mathrm{~mL})$ necessary for microorganisms for the synthesis of amino acids and nucleic acids. There were also mineral components present in this waste, which determined the correct course of biochemical processes in cells. In addition, potato wastewater contained only a few simple sugars $(0.73 \mathrm{~g} / 100 \mathrm{~mL})$, which are necessary to ensure favorable conditions for the 
Table 1 Characterization of waste glycerol fraction (Bioagra-Oil S.A., Tychy)

\begin{tabular}{llc}
\hline Parameter & Unit & Average value \pm SD \\
\hline Glycerol & $\mathrm{g} / 100 \mathrm{~g}$ & $60.29 \pm 0.38$ \\
Methanol & $\mathrm{g} / 100 \mathrm{~g}$ & $3.30 \pm 0.10$ \\
Sodium & $\mathrm{g} / 100 \mathrm{~mL}$ & $1.107 \pm 0.083$ \\
Calcium & $\mathrm{g} / 100 \mathrm{~mL}$ & $0.024 \pm 0.003$ \\
Potassium & $\mathrm{g} / 100 \mathrm{~mL}$ & $0.007 \pm 0.000$ \\
Phosphorus & $\mathrm{g} / 100 \mathrm{~mL}$ & $0.004 \pm 0.001$ \\
Magnesium & $\mathrm{g} / 100 \mathrm{~mL}$ & $0.003 \pm 0.001$ \\
pH & $-\log \left(\mathrm{H}^{+}\right)$ & $12.1 \pm 0.1$ \\
\hline
\end{tabular}

growth and biosynthesis of lipids and carotenoids. The chemical oxygen demand index is one of the most important parameters that characterizes the degree of wastewater treatment. Lubiewski et al. [23] reported that for potato wastewater, the value of this indicator is above $20,000 \mathrm{mg} / \mathrm{L}$. The value of COD ratio of potato wastewater used in this research was $30,820 \mathrm{mg} / \mathrm{L}$, which confirmed the presence of a high content of organic and inorganic compounds in this waste. These values are too high to allow this waste to be disposed of in natural conditions [24].

\section{Growth Screening of Yeasts in the Control and Experimental Media}

Microcultures of the Rhodotorula yeast were conducted in two control media-YPD and a medium containing deproteinized potato wastewater (PW), which was not enriched with an additional carbon source. A glycerol fraction collected from biodiesel production was added to the experimental media in such an amount that the final concentration of glycerol in the media ranged from 3 to $25 \%$. The doses of glycerol to the experimental media were selected on the basis of a review of the literature, which shows that in order to obtain a high biomass yield and efficient biosynthesis of carotenoids and lipids, a high amount of carbon source compounds must be present in the culture medium. This is particularly important for the biosynthesis of intracellular lipids in yeast cells, and the initial molar ratio $\mathrm{C} / \mathrm{N}$ plays a significant role $[25,26]$. In the prepared experimental media, the molar ratio $\mathrm{C} / \mathrm{N}$ ranged from $6 / 1$ to $68 / 1$ (Table 3 ).

On the basis of results of microcultures from the Bioscreen $\mathrm{C}$ system (Table 4), it was found that the Rhodotorula yeast could grow in the control and experimental media. However, because of the different sensitivities of the tested yeast strains to high glycerol concentrations

Table 2 Characterization of deproteinized potato wastewater

\begin{tabular}{llc}
\hline Parameter & Unit & Average value \pm SD \\
\hline Dry substance & $\mathrm{g} / 100 \mathrm{~mL}$ & $3.97 \pm 0.05$ \\
Total nitrogen & $\mathrm{g} / 100 \mathrm{~mL}$ & $0.232 \pm 0.007$ \\
Total protein & $\mathrm{g} / 100 \mathrm{~mL}$ & $1.45 \pm 0.05$ \\
Directly reducing sugars & $\mathrm{g} / 100 \mathrm{~mL}$ & $0.73 \pm 0.05$ \\
COD & $\mathrm{mg} \mathrm{O} / \mathrm{L}$ & $30,820 \pm 527$ \\
Potassium & $\mathrm{g} / 100 \mathrm{~mL}$ & $0.431 \pm 0.025$ \\
Phosphorus & $\mathrm{g} / 100 \mathrm{~mL}$ & $0.027 \pm 0.002$ \\
Magnesium & $\mathrm{g} / 100 \mathrm{~mL}$ & $0.024 \pm 0.001$ \\
Calcium & $\mathrm{g} / 100 \mathrm{~mL}$ & $0.016 \pm 0.001$ \\
Sodium & $\mathrm{g} / 100 \mathrm{~mL}$ & $0.006 \pm 0.000$ \\
\hline
\end{tabular}


Table 3 Molar $\mathrm{C} / \mathrm{N}$ ration in control and experimental media

\begin{tabular}{lc}
\hline Culture medium & C/N ratio \\
\hline YPD & 1 \\
PW & 0.6 \\
PW+G3\% & 6 \\
PW+G5\% & 10 \\
PW+G10\% & 22 \\
PW+G15\% & 35 \\
PW+G20\% & 51 \\
PW+G25\% & 68 \\
\hline
\end{tabular}

in the experimental media, the glycerol fraction must be added to the medium at the appropriate dose. The lowest resistance was found for the $R$. gracilis yeast strain, whose growth was completely inhibited in the medium with PW and $15 \%$ of glycerol. Rhodotorula glutinis yeast did not grow in a medium containing a $25 \%$ addition of glycerol, whereas the growth of $R$. mucilaginosa was inhibited in a medium containing $20 \%$ of this compound. Of the tested strains, only $R$. glutinis yeast showed greater or similar growth rate in media with potato wastewater and glycerol than in the control medium YPD $\left(\mu_{\max }=0.0356\right)$, and the highest value of this index $\left(\mu_{\max }=0.0398\right)$ was found in the PW+G3\% medium. Furthermore, the addition of glycerol to PW reduced the growth rate of $R$. mucilaginos $a$ and $R$. gracilis. The

Table 4 Parameters characterizing the growth of studied Rhodotorula yeast strains in experimental media based on microculture in Bioscreen $\mathrm{C}$ system

\begin{tabular}{|c|c|c|c|}
\hline Culture medium & $t_{\operatorname{lag}}[\mathrm{h}]$ & $t_{\log }[\mathrm{h}]$ & $\mu_{\max }\left(\mathrm{h}^{-1}\right)$ \\
\hline \multicolumn{4}{|c|}{ Rhodotorula glutinis } \\
\hline YPD & 2 & 18 & 0.0356 \\
\hline PW & 2 & 18 & 0.0348 \\
\hline $\mathrm{PW}+\mathrm{G} 3 \%$ & 2 & 18 & 0.0398 \\
\hline $\mathrm{PW}+\mathrm{G} 5 \%$ & 2 & 18 & 0.0341 \\
\hline $\mathrm{PW}+\mathrm{G} 10 \%$ & 8 & 20 & 0.0365 \\
\hline $\mathrm{PW}+\mathrm{G} 15 \%$ & 18 & 20 & 0.0331 \\
\hline $\mathrm{PW}+\mathrm{G} 20 \%$ & 18 & 22 & 0.0292 \\
\hline $\mathrm{PW}+\mathrm{G} 25 \%$ & \multicolumn{3}{|l|}{ No growth } \\
\hline \multicolumn{4}{|c|}{ Rhodotorula mucilaginosa } \\
\hline YPD & 4 & 20 & 0.0322 \\
\hline PW & 4 & 18 & 0.0318 \\
\hline $\mathrm{PW}+\mathrm{G} 3 \%$ & 6 & 20 & 0.0287 \\
\hline PW+G5\% & 12 & 34 & 0.0210 \\
\hline $\mathrm{PW}+\mathrm{G} 10 \%$ & 28 & 38 & 0.0176 \\
\hline $\mathrm{PW}+\mathrm{G} 15 \%$ & 56 & \multicolumn{2}{|c|}{ The logarithmic growth phase did not end up to $120 \mathrm{~h}$} \\
\hline $\mathrm{PW}+\mathrm{G} 20 \%$ & No growth & & \\
\hline $\mathrm{PW}+\mathrm{G} 25 \%$ & No growth & & \\
\hline \multicolumn{4}{|c|}{ Rhodotorula gracilis } \\
\hline YPD & 2 & 18 & 0.0401 \\
\hline PW & 2 & 16 & 0.0353 \\
\hline $\mathrm{PW}+\mathrm{G} 3 \%$ & 12 & 28 & 0.0230 \\
\hline $\mathrm{PW}+\mathrm{G} 5 \%$ & 52 & 30 & 0.0213 \\
\hline $\mathrm{PW}+\mathrm{G} 10 \%$ & 52 & 46 & 0.0134 \\
\hline $\mathrm{PW}+\mathrm{G} 15 \%$ & No growth & & \\
\hline $\mathrm{PW}+\mathrm{G} 20 \%$ & No growth & & \\
\hline $\mathrm{PW}+\mathrm{G} 25 \%$ & No growth & & \\
\hline
\end{tabular}


time of the adaptation phase was considerably lengthened, which may have resulted from the increase in the osmotic pressure of the media.

Glycerol belongs to osmotically active substances and significantly affects the osmotic potential of the environment [27]. High concentrations of glycerol in the media caused the appearance of the so-called osmotic stress in the cells, which significantly decreased or inhibited the growth of yeasts. An increase in the osmotic pressure of the environment could also reduce the permeability of cell membranes and cause the closure of specific transport channels, because of which the yeast was unable to use the nutrients present in the medium [28]. Yeasts could also synthesized specific osmoregulation substances [29], including glutamate, $\gamma$-aminobutyrate, trehalose, proline, glycine betaine, or choline [30], which probably lengthened the adaptation phase. Another factor that limited the growth of yeast in experimental media was the presence of other impurities introduced with the crude glycerol fraction. The addition of glycerol to the culture medium increased the content of methanol and other compounds present in this waste, which in higher concentrations became toxic to yeast cells [31].

In the next part of the study, including yeast cultures in shaker flasks, for $R$. glutinis and $R$. mucilaginosa yeast strains, media with PW and 3\%, 5\%, and $10 \%$ doses of glycerol were selected. Because of the significantly slower growth rate of $R$. gracilis yeast in the medium with $10 \%$ of glycerol, this variant was excluded, and the cultures of this strain were carried out in media supplemented with $3 \%$ and $5 \%$ addition of this compound.

\section{Biomass Yield}

The tested yeast strains showed the ability to grow and biosynthesize lipids and carotenoids in media with PW and glycerol. To obtain high biomass yield, it was required to select the appropriate initial concentration of glycerol, depending on the yeast strain. After $120 \mathrm{~h}$ of cultures on the shaker, the highest biomass yield for R. glutinis and $R$. mucilaginosa was found in media with $5 \%$ and $10 \%$ glycerol addition (approximately $28-32 \mathrm{~g}_{\text {d.w. }} / \mathrm{L}$ ), while for $R$. gracilis, the highest biomass yield (approximately $20-22 \mathrm{~g}_{\text {d.w. }} / \mathrm{L}$ ) was obtained in media with $3 \%$ or $5 \%$ addition of this compound (Fig. 1). The determined values of cellular biomass in experimental media were significantly higher than those after cultivation in the control YPD medium.

Previous studies $[20,32,33]$ have reported the use of glycerol as a carbon source for the cultivation of yeasts of the genus Rhodotorula. In these studies, various compounds

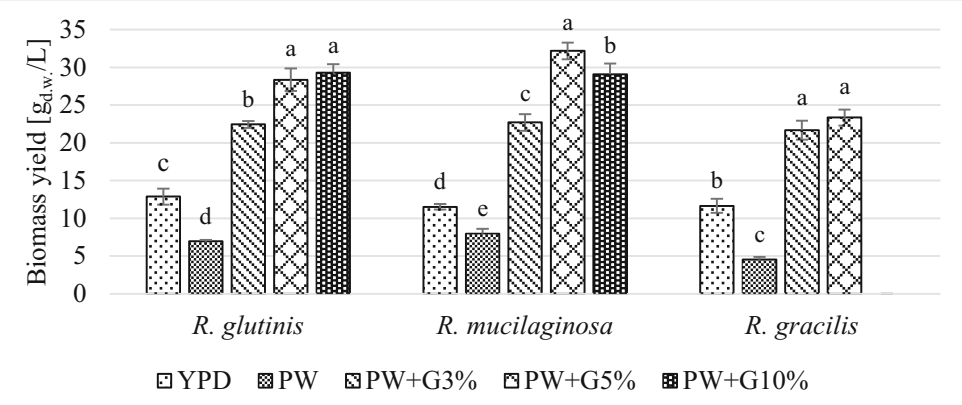

Fig. 1 Biomass yield of Rhodotorula yeast after $120 \mathrm{~h}$ of cultivation in control and experimental media (a, b, c... indexes mean homogeneous groups, Tukey's test, $\alpha=0.05$ ) 
(ammonium salts, yeast extract, or peptone) were used as a source of nitrogen. Saenge et al. [20] reported $R$. glutinis TISTR 5159 yeast culture in media containing 5\% and $9.5 \%$ glycerol and ammonium sulfate as a source of nitrogen. The yield of cellular biomass was only 5.15$5.65 \mathrm{~g}_{\text {d.w. }} / \mathrm{L}$, while the yield obtained in the present study was approximately $18-21 \mathrm{~g}_{\text {d.w. }} / \mathrm{L}$. Karamerou et al. [33] used a yeast extract as a nitrogen source and glycerol as a carbon source at a dose of $3.5 \%$. To obtain a high cell biomass yield (16.8 $\left.\mathrm{g}_{\text {d.w. }} / \mathrm{L}\right)$, cultures of $R$. glutinis CICC 31596 yeast were carried out for $192 \mathrm{~h}$. The cellular biomass yields from the genus Rhodotorula obtained in the abovementioned studies were significantly lower than those achieved in this study. Therefore, PW can be considered a substitute for commonly used nitrogen source compounds such as ammonium sulfate or yeast extract.

\section{The Use of Components from the Medium by Yeast}

The tested yeast strains of the genus Rhodotorula intensively metabolized reducing sugars, nitrogen compounds present in PW, and glycerol added into the media in the form of glycerol fraction. The total use of glycerol from culture media was dependent on the yeast strain and the level of glycerol added to the media. In a medium with 3\% addition of glycerol, after $120 \mathrm{~h}$, the total utilization of this compound was found to be above $97 \%$ (Table 5). After cultivation in the PW+G5\% medium, the total glycerol utilization level varied from 63 to $92 \%$ depending on the strain. Further, the total glycerol utilization level after cultivation in PW+G10\% medium for $R$. glutinis yeast and $R$. mucilaginosa was approximately $40 \%$. To increase the use of glycerol in these media, the time of cultivation should be extended.

The total level of nitrogen utilization from the experimental media by tested yeast strains of the genus Rhodotorula ranged from 52 to $67 \%$ (Table 5). The remainder was probably the nitrogen compounds in the form that were not assimilable by yeast. In addition to amino acids, peptides, and inorganic salts, PW contains Maillard reaction products, which are formed

Table 5 The percentage level of glycerol, nitrogen, and reducing sugars usage from the media, finally media $\mathrm{pH}$ and level of the COD index reduction after $120 \mathrm{~h}$ of cultivation Rhodotorula yeast

\begin{tabular}{|c|c|c|c|c|c|}
\hline Culture medium & $\begin{array}{l}\text { Level of glycerol } \\
\text { usage }(\%)\end{array}$ & $\begin{array}{l}\text { Level of nitrogen } \\
\text { usage }(\%)\end{array}$ & $\begin{array}{l}\text { Level of reducing } \\
\text { sugar usage }(\%)\end{array}$ & Finally medium $\mathrm{pH}$ & $\begin{array}{l}\text { Level } \\
\text { of COD index } \\
\text { reduction }(\%)\end{array}$ \\
\hline \multicolumn{6}{|c|}{ Rhodotorula glutinis } \\
\hline YPD & - & $32.1 \pm 3.5$ & $90.7 \pm 0.1$ & $8.7 \pm 0.3$ & - \\
\hline PW & - & $24.5 \pm 5.3$ & $75.9 \pm 3.4$ & $9.3 \pm 0.1$ & $43.4 \pm 5.3$ \\
\hline $\mathrm{PW}+\mathrm{G} 3 \%$ & $97.8 \pm 1.1$ & $62.1 \pm 0.8$ & $77.4 \pm 6.3$ & $8.7 \pm 0.1$ & $81.0 \pm 2.6$ \\
\hline $\mathrm{PW}+\mathrm{G} 5 \%$ & $79.5 \pm 3.6$ & $61.1 \pm 5.4$ & $72.2 \pm 1.8$ & $8.7 \pm 0.2$ & $77.6 \pm 3.5$ \\
\hline $\mathrm{W}+\mathrm{G} 10 \%$ & $39.5 \pm 2.7$ & $59.8 \pm 7.0$ & $72.7 \pm 4.4$ & $8.5 \pm 0.2$ & $49.1 \pm 5.1$ \\
\hline \multicolumn{6}{|c|}{ Rhodotorula mucilaginosa } \\
\hline YPD & - & $19.1 \pm 4.6$ & $91.5 \pm 1.4$ & $8.4 \pm 0.2$ & - \\
\hline PW & - & $28.7 \pm 6.7$ & $71.6 \pm 2.3$ & $9.5 \pm 0.1$ & $49.0 \pm 6.6$ \\
\hline $\mathrm{PW}+\mathrm{G} 3 \%$ & $98.0 \pm 1.3$ & $66.4 \pm 2.2$ & $72.6 \pm 3.6$ & $8.7 \pm 0.2$ & $83.2 \pm 1.1$ \\
\hline $\mathrm{PW}+\mathrm{G} 5 \%$ & $91.9 \pm 4.1$ & $67.5 \pm 3.3$ & $73.9 \pm 3.2$ & $8.6 \pm 0.2$ & $82.6 \pm 1.2$ \\
\hline $\mathrm{PW}+\mathrm{G} 10 \%$ & $41.1 \pm 1.8$ & $63.0 \pm 6.1$ & $74.9 \pm 1.7$ & $8.6 \pm 0.1$ & $54.7 \pm 3.6$ \\
\hline \multicolumn{6}{|c|}{ Rhodotorula gracilis } \\
\hline YPD & - & $33.6 \pm 4.8$ & $90.3 \pm 1.8$ & $8.5 \pm 0.2$ & - \\
\hline PW & - & $32.1 \pm 4.5$ & $78.5 \pm 2.1$ & $9.4 \pm 0.2$ & $39.5 \pm 6.6$ \\
\hline $\mathrm{PW}+\mathrm{G} 3 \%$ & $99.3 \pm 0.2$ & $65.0 \pm 2.6$ & $78.1 \pm 2.4$ & $8.4 \pm 0.1$ & $81.8 \pm 1.3$ \\
\hline $\mathrm{PW}+\mathrm{G} 5 \%$ & $62.9 \pm 2.7$ & $52.5 \pm 4.6$ & $72.6 \pm 3.5$ & $8.4 \pm 0.2$ & $63.1 \pm 3.6$ \\
\hline
\end{tabular}


mainly in the deproteination stage. At a higher temperature, condensation occurs between the carbonyl groups of the sugars and the primary amino groups of the amino acids. The imines thus formed then undergo a spontaneous rearrangement to the so-called Amadori compounds, which in turn polymerize to brown products $[34,35]$. Thus, the compounds formed as a result of the Maillard reaction were not used by yeasts during cultivation. The remaining nitrogen in the media could also be secondary yeast metabolites such as ammonia.

The content of reducing sugars in media decreased from approximately 0.7 to $0.2 \%$. PW contains mainly simple sugars such as glucose, rhamnose, and galactose [23], of which the tested Rhodotorula yeast strains assimilate glucose, whereas the use of galactose and rhamnose is strain dependent [36]. Thus, it can be assumed that the residue in media with PW was galactose and rhamnose.

After $120 \mathrm{~h}$ of cultivation, the highest $\mathrm{pH}(9.3-9.6)$ was shown by control media. Strong alkalization also occurred in the experimental media, and the $\mathrm{pH}$ values (8.4-8.7) were similar for all tested yeast strains. Alkalization probably occurred due to secretion of secondary metabolites formed during the transformation of nitrogen compounds, which include ammonia. The reason for the alkalization could also be the degradation of AMP (adenosine monophosphate) to IMP (inosine monophosphate) and ammonium ions [37, 38]. It is considered that the optimal $\mathrm{pH}$ value of the cultivation medium for most species of the genus Rhodotorula ranges from 5.0 to 6.0 [39]; therefore, the alkalization of the medium may be a stressful factor for cells. It is known that alkalization primarily affects the metabolism and uptake of nutrients by yeast [40, 41]. However, in the present study, biomass yields and the level of nutrient utilization from the media were high, which indicates that the alkalization did not negatively affect the growth of the tested yeast strains.

The chemical oxygen demand is an important parameter that characterizes the degree of wastewater treatment. It is calculated as the amount of oxygen taken from the oxidant (potassium dichromate) for the oxidation of organic and some inorganic compounds such as nitrites, sulfides, and sulfites. The maximum value of COD for wastewater that can be discharged into the soil or waters according to the Regulation of the Polish Ministry of the Environment from 2014 is $125 \mathrm{mg} / \mathrm{L}$. COD values were determined for deproteinized PW and experimental media before yeast culture and after $120 \mathrm{~h}$. Accordingly, the reduction degree of COD for particular yeast cultures was calculated.

Cultures of yeast of the genus Rhodotorula in a medium containing PW reduced the COD index from 29,847 to $15,220-18,033 \mathrm{mg} / \mathrm{L}$ depending on the strain. The low total reduction rate (below 50\%) in the control medium containing PW resulted from the weak use of nitrogen. Supplementation with glycerol from potato wastewater significantly increased the initial COD value of substrates to 70,997 (PW+G3\%), 101,073 (PW+G5\%), and 175,960 mg/ $\mathrm{L}(\mathrm{PW}+\mathrm{G} 10 \%)$. After $120 \mathrm{~h}$ of cultivation of the tested yeast strains of the genus Rhodotorula, the highest reduction rate $(81.0-83.3 \%)$ and the lowest COD values $(11,927-13,513 \mathrm{mg} / \mathrm{L})$ were found in the medium with $3 \%$ glycerol addition. The values of COD in these conditions were significantly lower than those after cultivation in the control medium with PW, which was caused by the higher use of carbon and nitrogen sources.

\section{Biosynthesis of Lipids by the Yeast Strains and Fatty Acid Composition}

The tested yeast strains synthesized intracellular lipids, and their content was dependent on the strain and the type of culture medium. After cultivation of the yeast strains in experimental media, the lipid content did not exceed $16 \mathrm{~g} / 100 \mathrm{~g}_{\text {d.w. }}$ (Fig. 2). It is worth noting that after the 


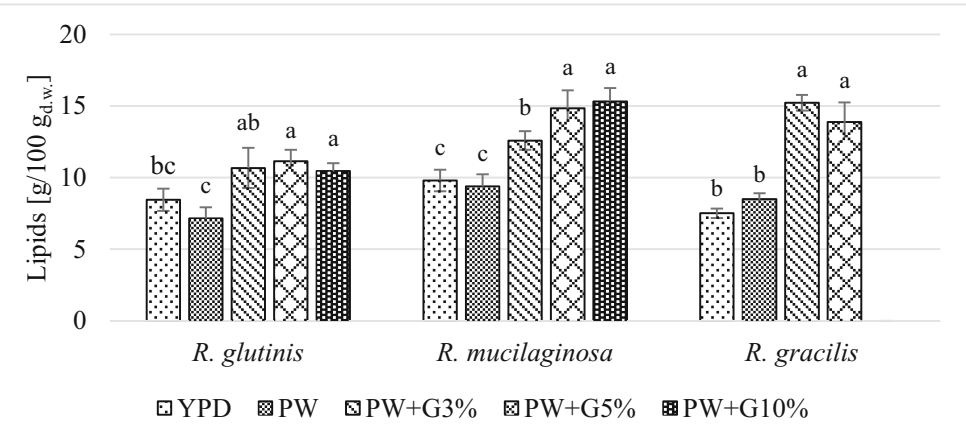

Fig. 2 Total lipids content in Rhodotorula yeast biomass after $120 \mathrm{~h}$ of cultivation in control and experimental media ( $\mathrm{a}, \mathrm{b}, \mathrm{c} .$. indexes mean homogeneous groups, Tukey's test, $\alpha=0.05$ )

cultivation of $R$. mucilaginosa and $R$. gracilis yeast in media with PW and glycerol, the lipid content was significantly higher (approximately $15 \mathrm{~g} / 100 \mathrm{~g}_{\text {d.w. }}$ ) than in the control media (approximately 7-9 $\mathrm{g} / 100 \mathrm{~g}_{\text {d.w. }}$ ). This may have resulted from the fact that glycerol is the skeleton of the structure of triacylglycerol molecules, whereby its presence in the medium may induce the biosynthesis of these compounds by yeast [42].

In the experimental media used, the nitrogen content was probably too high for increased production of lipids in yeast cells. Under conditions of deficiency of nitrogen compounds in the culture environment, AMP deaminase is activated, which catalyzes the reaction of degradation of AMP to IMP and ammonium ions. Thereafter, citrate accumulates in the mitochondria, from where it is then transported to the cytoplasm and decomposed to acetylCoA and oxaloacetate by ATP citrate lyase. The acetyl-CoA molecules are a substrate for the synthesis of fatty acids [43]. In a culture medium containing a limited amount of nitrogen (yeast extract $0.5 \mathrm{~g} / \mathrm{L}$, ammonium sulfate $0.31 \mathrm{~g} / \mathrm{L})$ and glucose $(50 \mathrm{~g} / \mathrm{L})$ as a carbon source, Jiru et al. [44] obtained biomass containing 56\% lipids in the dry substance of the cell by using Rhodotorula kratochvilovae SY89 yeast.

The $\mathrm{C} / \mathrm{N}$ molar ratio depends on the content of carbon and nitrogen source compounds in culture media. In the culture media with PW and glycerol $*(3 \%, 5 \%$, or $10 \%)$ used in this study, it ranged from $6 / 1$ to $22 / 1$ (Table 3). Low values of this parameter may be due to the fact that the yeast did not fit the criterion of oleaginous microorganisms. Papanikolaou and Aggelis [6] reported that a $\mathrm{C} / \mathrm{N}$ ratio higher than 20 stimulates lipid biosynthesis by yeast, while lower values indicate a positive influence on the growth of cellular biomass, which was also

Table 6 The values of volumetric yield of lipid $(\mathrm{g} / \mathrm{L})$ and volumetric lipid productivity $(\mathrm{g} / \mathrm{L} / \mathrm{h})$ in control and experimental media

\begin{tabular}{|c|c|c|c|c|c|c|}
\hline \multirow[t]{2}{*}{ Culture medium } & \multicolumn{2}{|l|}{ R. glutinis } & \multicolumn{2}{|c|}{ R. mucilaginosa } & \multicolumn{2}{|l|}{ R. gracilis } \\
\hline & $Y_{\mathrm{L}}$ & $Q_{\mathrm{L}}$ & $Y_{\mathrm{L}}$ & $Q_{\mathrm{L}}$ & $Y_{\mathrm{L}}$ & $Q_{\mathrm{L}}$ \\
\hline YPD & $1.08 \pm 0.01$ & $0.009 \pm 0.000$ & $1.13 \pm 0.10$ & $0.009 \pm 0.001$ & $0.88 \pm 0.10$ & $0.007 \pm 0.001$ \\
\hline PW & $0.49 \pm 0.04$ & $0.004 \pm 0.000$ & $0.75 \pm 0.12$ & $0.006 \pm 0.001$ & $0.38 \pm 0.02$ & $0.003 \pm 0.000$ \\
\hline $\mathrm{PW}+\mathrm{G} 3 \%$ & $2.39 \pm 0.27$ & $0.020 \pm 0.002$ & $2.86 \pm 0.14$ & $0.024 \pm 0.001$ & $3.30 \pm 0.08$ & $0.027 \pm 0.001$ \\
\hline PW+G5\% & $3.15 \pm 0.07$ & $0.026 \pm 0.001$ & $4.76 \pm 0.25$ & $0.040 \pm 0.002$ & $3.23 \pm 0.19$ & $0.027 \pm 0.002$ \\
\hline $\mathrm{PW}+\mathrm{G} 10 \%$ & $3.06 \pm 0.26$ & $0.026 \pm 0.002$ & $4.46 \pm 0.41$ & $0.037 \pm 0.003$ & - & - \\
\hline
\end{tabular}

$Y_{\mathrm{L}}$, volumetric yield of lipid; $Q_{\mathrm{L}}$, volumetric lipid productivity 
Table 7 The range of changes in the content of selected fatty acids (\%) in lipids extracted from the Rhodotorula yeast biomass after $120 \mathrm{~h}$ of cultivation in experimental media (PW+G3\%, PW+G5\%, and PW+G10\%) and in the control medium YPD

\begin{tabular}{|c|c|c|c|c|c|c|}
\hline \multirow{2}{*}{$\begin{array}{l}\text { Fatty } \\
\text { acid }\end{array}$} & \multicolumn{2}{|l|}{ R. glutinis } & \multicolumn{2}{|l|}{ R. mucilaginosa } & \multicolumn{2}{|l|}{$R$. gracilis } \\
\hline & $\begin{array}{l}\text { Control medium } \\
\text { (YPD) }\end{array}$ & $\begin{array}{l}\text { Experimental } \\
\text { media }\end{array}$ & $\begin{array}{l}\text { Control medium } \\
\text { (YPD) }\end{array}$ & $\begin{array}{l}\text { Experimental } \\
\text { media }\end{array}$ & $\begin{array}{l}\text { Control medium } \\
\text { (YPD) }\end{array}$ & $\begin{array}{l}\text { Experimental } \\
\text { media }\end{array}$ \\
\hline C16:0 & 23.3 & $20.1-21.3$ & 29.5 & $10.8-12.3$ & 14.9 & $11.5-12.3$ \\
\hline C18:0 & 15.6 & 7.9-9.4 & 22.7 & $9.3-10.9$ & 3.2 & $3.1-4.9$ \\
\hline C18:1 & 37.3 & $43.0-46.9$ & 38.5 & $62.8-67.8$ & 56.8 & $65.2-65.9$ \\
\hline C18:2 & 11.4 & $14.5-17.3$ & 1.6 & $1.9-3.0$ & 15.9 & $10.6-12.6$ \\
\hline C18:3 & 2.4 & $2.2-3.2$ & 0.2 & $0.1-0.3$ & 1.6 & $2.0-2.4$ \\
\hline C20:0 & 2.8 & $1.9-2.5$ & 1.5 & $1.7-3.0$ & 2.9 & $1.1-1.4$ \\
\hline
\end{tabular}

C16:0 palmitic acid, C18:0 stearic acid, C18:1 oleic acid, C18:2 linoleic acid, C18:3 linolenic acid, C20:0 arachidic acid

observed in the present study. This is because the available forms of carbon and nitrogen are mainly used to meet the cells' need related to multiplication and development. When the nitrogen availability in the medium is reduced, the rate of growth decreases and the excess carbon is used to synthesize lipids as a storage substance [45].

Another factor that could affect the low content of lipids in the yeast biomass was the high $\mathrm{pH}$ of culture media, which was above 8 (Table 5). The alkalization of the cultivation medium induces the expression of genes responsible for glucose metabolism, which results in the enhanced synthesis of polysaccharides such as trehalose [40, 41]. In the media containing both simple sugars and glycerol, there was an overproduction of intracellular polysaccharides instead of lipid biosynthesis. The profitability of microbial lipid production, in addition to the lipid content in biomass, is primarily determined by the yield of cellular biomass and the time of cultivation, which is expressed by indicators of volume efficiency and productivity of lipid biosynthesis (Table 6). The highest value of volume efficiency (4.46-4.76 g/L) and

Table 8 Percentages of fatty acids: saturated (SFAs), monounsaturated (MUFAs) and polyunsaturated (PUFAs) after $120 \mathrm{~h}$ of cultivation of Rhodotorula yeast in control and experimental media

\begin{tabular}{|c|c|c|c|}
\hline Culture medium & SFAs & MUFAs & PUFAs \\
\hline \multicolumn{4}{|c|}{ Rhodotorula glutinis } \\
\hline YPD & $45.6 \pm 1.0$ & $40.6 \pm 2.6$ & $13.8 \pm 3.6$ \\
\hline PW & $35.4 \pm 1.5$ & $48.4 \pm 3.1$ & $16.2 \pm 2.2$ \\
\hline $\mathrm{PW}+\mathrm{G} 3 \%$ & $34.4 \pm 3.9$ & $46.1 \pm 4.8$ & $19.5 \pm 1.4$ \\
\hline PW+G5\% & $33.9 \pm 1.8$ & $48.9 \pm 1.4$ & $17.2 \pm 2.6$ \\
\hline $\mathrm{PW}+\mathrm{G} 10 \%$ & $35.4 \pm 4.3$ & $45.1 \pm 2.5$ & $19.5 \pm 1.8$ \\
\hline \multicolumn{4}{|c|}{ Rhodotorula mucilaginosa } \\
\hline YPD & $57.4 \pm 3.6$ & $40.0 \pm 3.4$ & $2.6 \pm 0.4$ \\
\hline PW & $46.4 \pm 4.2$ & $49.6 \pm 4.7$ & $4.0 \pm 0.5$ \\
\hline $\mathrm{PW}+\mathrm{G} 3 \%$ & $27.5 \pm 0.3$ & $69.4 \pm 0.7$ & $3.1 \pm 0.6$ \\
\hline $\mathrm{PW}+\mathrm{G} 5 \%$ & $29.1 \pm 0.3$ & $68.5 \pm 0.5$ & $2.4 \pm 0.4$ \\
\hline $\mathrm{PW}+\mathrm{G} 10 \%$ & $31.5 \pm 3.5$ & $64.7 \pm 3.4$ & $3.8 \pm 0.1$ \\
\hline \multicolumn{4}{|c|}{ Rhodotorula gracilis } \\
\hline YPD & $23.8 \pm 0.8$ & $58.3 \pm 1.8$ & $17.9 \pm 2.1$ \\
\hline PW & $22.7 \pm 3.0$ & $63.7 \pm 1.7$ & $13.6 \pm 1.5$ \\
\hline $\mathrm{PW}+\mathrm{G} 3 \%$ & $19.0 \pm 4.2$ & $68.0 \pm 2.8$ & $13.0 \pm 2.3$ \\
\hline $\mathrm{PW}+\mathrm{G} 5 \%$ & $17.9 \pm 1.8$ & $67.0 \pm 1.9$ & $15.1 \pm 1.9$ \\
\hline
\end{tabular}




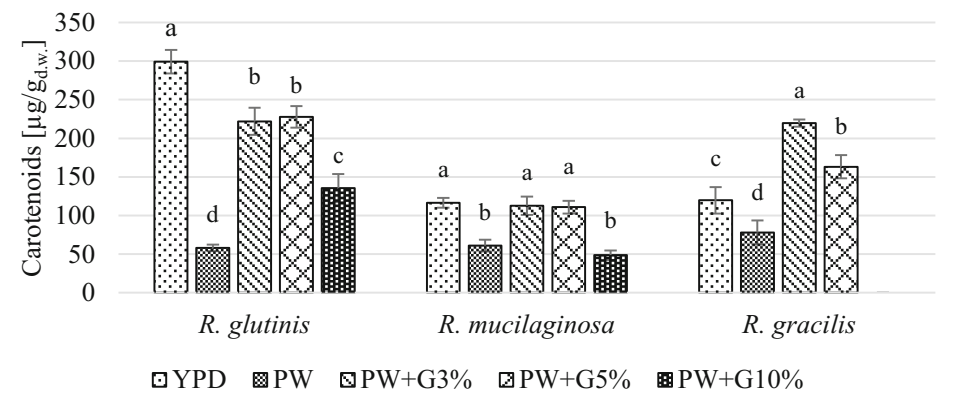

Fig. 3 Total carotenoids content in Rhodotorula yeast biomass after $120 \mathrm{~h}$ of cultivation in control and experimental media (a, b, c... indexes mean homogeneous groups, Tukey's test, $\alpha=0.05$ )

productivity $(0.037-0.040 \mathrm{~g} / \mathrm{L} / \mathrm{h})$ was obtained after $120 \mathrm{~h}$ of $R$. mucilaginosa culture in experimental media $\mathrm{PW}+\mathrm{G} 5 \%$ and $\mathrm{PW}+\mathrm{G} 10 \%$. For $R$. glutinis yeast, the values of these indicators were significantly lower $(3.1 \mathrm{~g} / \mathrm{L}$ and $0.026 \mathrm{~g} / \mathrm{L} / \mathrm{h}$, respectively), because of the lower intracellular lipid content in biomass. The volumetric yields after cultivation of $R$. gracilis yeast in the media $\mathrm{PW}+\mathrm{G} 3 \%$ and $\mathrm{PW}+\mathrm{G} 5 \%$ were similar and amounted to $3.2-$ $3.3 \mathrm{~g} / \mathrm{L}$, which resulted from the lower yields of cellular biomass. The productivity of lipid biosynthesis in these conditions was $0.027 \mathrm{~g} / \mathrm{L} / \mathrm{h}$. In the control media, the values of these indicators were several times lower than those in the experimental media (Table 6).

Table 7 shows the percentages of palmitic, stearic, oleic, linoleic, linolenic, and arahinic acids. Microbial lipids also contained acids such as myristic, palmitoleic, heptadecanoic, behenic, and lignoceric acids, and their content did not exceed 2\%. During cultivation in media with PW and glycerol, there was a reduction in the content of saturated fatty acids, i.e., palmitic and stearic acids, in lipids synthesized by the yeast strains tested compared with that in the control medium YPD. The content of monounsaturated acids increased due to the increase in oleic acid. The level of this acid was the highest (62-68\%) for R. mucilaginosa and $R$. gracilis yeast strains, while for $R$. glutinis yeast, the level of this acid was significantly less (43-47\%). In lipids synthesized by the yeast $R$. glutinis and $R$. gracilis, a significant amount of linoleic acid, whose share was $>17 \%$, was also identified.

Comparing the obtained results with the data on the composition of fatty acids of vegetable oils, it was found that the microbial lipids synthesized by $R$. gracilis yeast in media with PW and glycerol have a similar composition to olive oil. Orsavova et al. [46] determined the percentage of fatty acids in olive oil. The content of palmitic acid (16.5\%), stearic acid (2.3\%),

Table 9 The values of volumetric yield of carotenoids $(\mathrm{mg} / \mathrm{L})$ and volumetric carotenoids productivity $(\mathrm{mg} / \mathrm{L} / \mathrm{h})$ in control and experimental media

\begin{tabular}{|c|c|c|c|c|c|c|}
\hline \multirow[t]{2}{*}{ Culture medium } & \multicolumn{2}{|l|}{ R. glutinis } & \multicolumn{2}{|c|}{ R. mucilaginosa } & \multicolumn{2}{|l|}{ R. gracilis } \\
\hline & $Y_{\mathrm{Car}}$ & $Q_{\mathrm{Car}}$ & $Y_{\mathrm{Car}}$ & $Q_{\mathrm{Car}}$ & $Y_{\mathrm{Car}}$ & $Q_{\mathrm{Car}}$ \\
\hline YPD & $3.84 \pm 0.19$ & $0.032 \pm 0.002$ & $1.34 \pm 0.04$ & $0.011 \pm 0.000$ & $1.40 \pm 0.24$ & $0.012 \pm 0.002$ \\
\hline PW & $0.40 \pm 0.04$ & $0.003 \pm 0.000$ & $0.48 \pm 0.05$ & $0.004 \pm 0.000$ & $0.35 \pm 0.04$ & $0.003 \pm 0.000$ \\
\hline $\mathrm{PW}+\mathrm{G} 3 \%$ & $4.98 \pm 0.48$ & $0.042 \pm 0.004$ & $2.56 \pm 0.27$ & $0.021 \pm 0.002$ & $4.76 \pm 0.27$ & $0.040 \pm 0.002$ \\
\hline PW+G5\% & $6.46 \pm 0.53$ & $0.054 \pm 0.004$ & $3.57 \pm 0.38$ & $0.030 \pm 0.003$ & $3.82 \pm 0.52$ & $0.032 \pm 0.004$ \\
\hline $\mathrm{PW}+\mathrm{G} 10 \%$ & $3.96 \pm 0.39$ & $0.033 \pm 0.003$ & $1.42 \pm 0.24$ & $0.012 \pm 0.002$ & - & - \\
\hline
\end{tabular}

$Y_{\text {Car }}$,volumetric yield of carotenoids; $Q_{\text {Car }}$, volumetric carotenoids productivity 


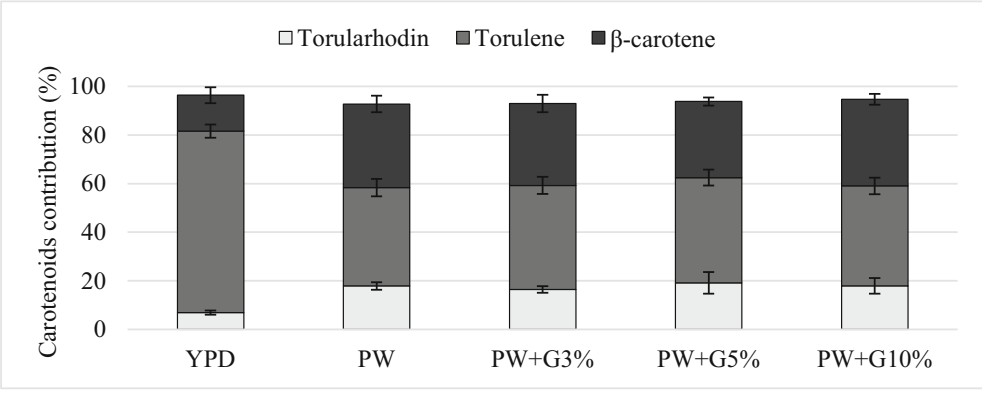

Fig. 4 Carotenoid profile synthesized by R. glutinis after $120 \mathrm{~h}$ of cultivation in control and experimental media

oleic acid (66.4\%), and linoleic acid (16.4\%) was similar to that of acids in lipids synthesized by yeast $R$. gracilis in experimental media. Further, the overall share of SFAs (19.4\%), MUFAs (71.1\%), and PUFAs (18.2\%) in olive oil was similar to that of the lipids synthesized by this yeast strain: SFAs (approximately 19\%), MUFAs (approximately 67\%), and PUFAs (approximately 14\%) (Table 8).

\section{Biosynthesis of Carotenoids by the Yeast and Their Profile}

The content of carotenoids in biomass depended on the yeast strain and the composition of the culture medium (Fig. 3). Rhodotorula glutinis synthesized significantly less total carotenoids $\left(135-228 \mu \mathrm{g} / \mathrm{g}_{\text {d.w. }}\right)$ in the experimental media with PW and glycerol than in the YPD control medium $\left(300 \mu \mathrm{g} / \mathrm{g}_{\text {d.w. }}\right)$. Rhodotorula mucilaginosa biomass was characterized by the lowest total carotenoid content among the tested strains. The highest total carotenoid content of these compounds (ok. $110 \mu \mathrm{g} / \mathrm{g}_{\text {d.w. }}$ ) was found after cultivation in the YPD medium and in experimental media PW+G3\% and PW+G5\%. Similar to $R$. glutinis yeast, a decrease was noted in the total carotenoid content in $R$. mucilaginosa yeast biomass from the control medium PW and the experimental medium PW+G10\%. Rhodotorula gracilis yeast synthesized significantly more total carotenoids when grown in a medium with PW and $3 \%$ glycerol $\left(220 \mu \mathrm{g} / \mathrm{g}_{\text {d.w. }}\right)$ than in the control medium YPD $\left(120 \mu \mathrm{g} / \mathrm{g}_{\text {d.w. }}\right)$. El-Banna et al. [47] proposed that the content of carotenoids in yeast biomass could be considered low for amount $<100 \mu \mathrm{g} /$ $\mathrm{g}_{\text {d.w. }}$, the average for $101-500 \mu \mathrm{g} / \mathrm{g}_{\text {d.w. }}$, and high for $>500 \mu \mathrm{g} / \mathrm{g}_{\text {d.w. }}$. On the basis of this criterion, it can be considered that the tested yeast strains of the genus Rhodotorula were average producers of carotenoids.

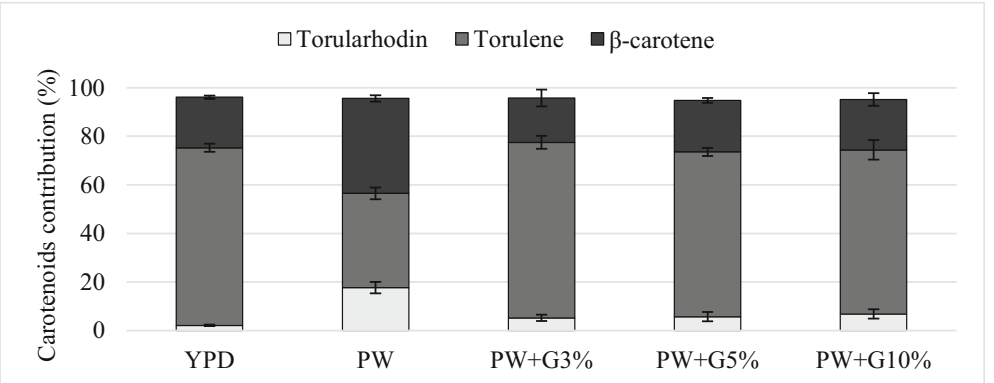

Fig. 5 Carotenoid profile synthesized by R. mucilaginosa after $120 \mathrm{~h}$ of cultivation in control and experimental media 


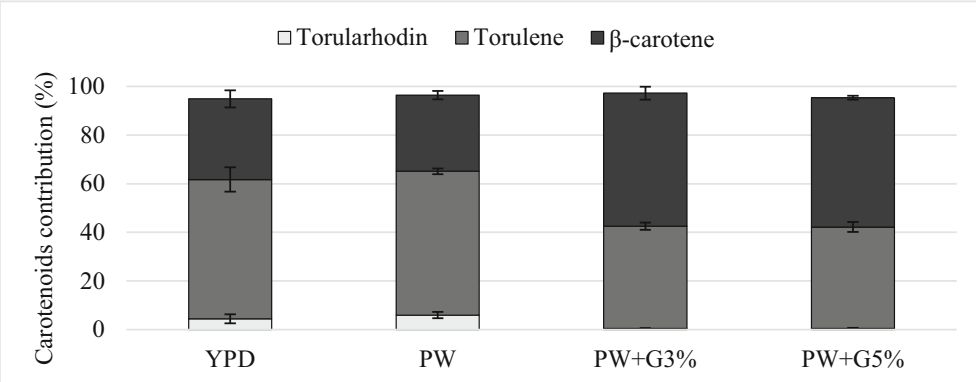

Fig. 6 Carotenoid profile synthesized by R. gracilis after $120 \mathrm{~h}$ of cultivation in control and experimental media

Analysis of the obtained results indicates that $10 \%$ concentration of glycerol inhibited the biosynthesis of carotenoid pigments by yeast. The phenomenon of limiting the production of carotenoids by $R$. glutinis yeast in media containing a high concentration of glycerol was reported by Saenge et al. [20] and Razavi et al. [48] for the yeast Sporobolomyces ruberrimus. High glucose concentration in the medium can also lead to a reduction in the efficiency of carotenoid biosynthesis by the Rhodotorula yeast [49]. In the yeast Phaffia rhodozyma (synonym Xanthophyllomyces dendrorhous), increased glucose suppresses the biosynthesis of carotenoids due to the occurrence of the Crabtree effect [50, 51]. Although yeasts of the genus Rhodotorula are considered to be Crabtree-negative [36], some strains may produce ethanol [52]. Perhaps, the reduction of carotenoid biosynthesis noted in the present study in media with $10 \%$ added glycerol was due to the Crabtree effect.

The highest volumetric yield of carotenoid biosynthesis $(6.46 \mathrm{mg} / \mathrm{L})$ was found after the cultivation of $R$. glutinis yeast in the medium with PW supplemented with $5 \%$ glycerol. In these conditions, the productivity of carotenoid biosynthesis was $0.054 \mathrm{mg} / \mathrm{L} / \mathrm{h}$. For the remaining strains, $Y_{\mathrm{Car}}$ and $Q_{\mathrm{Car}}$ values did not exceed $5 \mathrm{mg} / \mathrm{L}$ and $0.042 \mathrm{mg} / \mathrm{L} / \mathrm{h}$, respectively (Table 9). Buzzini and Martini [53] cultivated R. glutinis DBVPG 3853 yeast in media containing various sources of carbon and nitrogen. The high content of total carotenoids $\left(630 \mu \mathrm{g} / \mathrm{g}_{\text {d.w. }}\right)$ synthesized yeast cultivation in medium with concentrated grape must. However, due to the much lower biomass yield, the value of volumetric biosynthesis yield $(5.95 \mathrm{mg} / \mathrm{L})$ was comparable with that obtained in this study.

The analysis of the profile showed different proportions of $\beta$-carotene, torulene, and torularhodin depending on the yeast strain and the composition of the medium (Figs. 4, 5, 6). During cultivation in the YPD control medium, R. glutinis yeast synthesized the largest amount of torulene (approximately 75\%). The use of culture medium with PW and glycerol contributed to the increase in the proportion of $\beta$-carotene (31.4-36.5\%) in comparison with the control culture. The addition of glycerol to PW contributed to the increase in $\beta$-carotene biosynthesis, and the proportion of this compound was approximately $54 \%$. In these conditions, a lower proportion of torulene was noted (approximately 42\%). The carotenoid fraction synthesized by $R$. mucilaginosa yeast was dominated by torulene, and its proportion after cultivation in the YPD medium and experimental media was similar and amounted to approximately $70 \%$. The use of PW for the cultivation of $R$. glutinis and R. mucilaginosa yeast resulted in a significant increase in the production of torularhodin compared with that in the culture carried out in the control medium YPD. The highest proportion of this carotenoid fraction (17.9\%) was found after the cultivation of $R$. glutinis yeast in the PW medium, and this strain synthesized the highest amount of torularhodin among the tested strains. 


\section{Conclusions}

The study showed that it is possible to simultaneously biosynthesize lipids and carotenoids by $R$. glutinis, $R$. mucilaginosa, and $R$. gracilis yeast when growing in a medium containing only waste glycerol and deproteinized PW. The use of these substrates resulted in increased lipid biosynthesis in the cells of yeast strains (10.5-15.2 g/100 $\left.\mathrm{g}_{\text {d.w. }}\right)$ as compared with that in the YPD control medium (7.1-9.8 g/100 $\left.\mathrm{g}_{\text {d.w. }}\right)$. The fatty acid composition of the lipid fractions was dependent on the yeast strain and culture conditions, with oleic, palmitic, stearic, and linoleic acids dominating in them. On the basis of the profile of individual fatty acids and the proportions of SFAs, MUFAs, and PUFAs, it was found that the lipids synthesized by $R$. gracilis yeast in a medium with PW and glycerol had a composition similar to that of olive oil. At the same time, the yeast synthesized carotenoid pigments with an average yield (approximately $230 \mu \mathrm{g} / \mathrm{g}_{\text {d.w. }}$ ), and the analysis of the profile showed that the highest proportions were found for torulene and $\beta$-carotene. The results of the present research revealed that biomass of tested yeast strains obtained after cultivation in media with waste glycerol and deproteinized PW could become a source of microbial lipids containing natural antioxidants in the form of carotenoids. These compounds also exhibit the properties of provitamin A, which enables to use the yeast biomass, particularly that of $R$. gracilis, as a valuable feed additive.

Acknowledgments The authors thank Dr. Lidia Reczek for her help in determining the COD index. The authors also thank Translmed (Cedar Hill, TX, USA), a proofreading and copyediting company, for helping in copyediting this manuscript.

Funding Information This work was supported by the grant from the Polish Ministry of Science and Higher Education for the implementation of the project for young scientists (Grant No. 505-10-092800-M00332-99).

\section{Compliance with Ethical Standards}

Conflict of Interest The authors declare that they have no conflicts of interest.

Ethical Approval This article does not contain any studies with human participants or animals performed by any of the authors.

Open Access This article is distributed under the terms of the Creative Commons Attribution 4.0 International License (http://creativecommons.org/licenses/by/4.0/), which permits unrestricted use, distribution, and reproduction in any medium, provided you give appropriate credit to the original author(s) and the source, provide a link to the Creative Commons license, and indicate if changes were made.

\section{References}

1. Sitepu, I. R., Garay, L. A., Sestric, R., Levin, D., Block, D. E., German, J. B., \& Boundy-Mills, K. L. (2014). Oleaginous yeasts for biodiesel: current and future trends in biology and production. Biotechnology Advances, 32(7), 1336-1360.

2. Kot, A. M., Błażejak, S., Kurcz, A., \& Gientka, I. (2015). Drożdże jako potencjalne źródło tłuszczu mikrobiologicznego. Postepy Mikrobiologii, 54, 364-373.

3. Kot, A. M., Błażejak, S., Kurcz, A., Gientka, I., \& Kieliszek, M. (2016). Rhodotorula glutinis - potential source of lipids, carotenoids, and enzymes for use in industries. Applied Microbiology and Biotechnology, 100(14), 6103-6117.

4. Kot, A. M., Błażejak, S., Gientka, I., Kieliszek, M., \& Bryś, J. (2018). Torulene and torularhodin: "new" fungal carotenoids for industry? Microbial Cell Factories, 17(1), 49. 
5. Kurcz, A., Błażejak, S., Kot, A. M., \& Bzducha-Wróbel, A. (2016). Wykorzystanie odpadów pochodzących z przemysłu rolnospożywczego do produkcji biomasy drożdży paszowych Candida utilis. Postępy Mikrobiologii, 55(1), 19-26.

6. Papanikolaou, S., \& Aggelis, G. (2011). Lipids of oleaginous yeasts. Part I: biochemistry of single cell oil production. European Journal of Lipid Science and Technology, 113(8), 1031-1051.

7. Dzwonkowski, W. (2017). Dobre zbiory ziemniaków i rekordowy eksport skrobi. https://www.polskieradio. pl/42/5202/Artykul/1736542,Dobre-zbiory-ziemniakow-i-rekordowy-eksport-skrobi

8. Miedzianka, J., Pęksa, A., Pokora, M., Rytel, E., Tajner-Czopek, A., \& Kita, A. (2014). Improving the properties of fodder potato protein concentrate by enzymatic hydrolysis. Food Chemistry, 159, 512-518.

9. Kot, A. M., Błażejak, S., Kurcz, A., \& Gientka, I. (2015). Biodegradation of deproteinized potato wastewater and glycerol during cultivation of Rhodotorula glutinis yeast. Electronic Journal of Biotechnology, 18(6), 428-432.

10. Thompson, J. C., \& He, B. B. (2006). Characterization of crude glycerol from biodiesel production from multiple feedstocks. Applied Engineering in Agriculture, 22(2), 261-265.

11. Moser, B. R. (2009). Biodiesel production, properties, and feedstocks. In Vitro Cellular and Developmental Biology - Plant, 45(3), 229-266.

12. Yang, F., Hanna, M. A., \& Sun, R. (2012). Value-added uses for crude glycerol-a byproduct of biodiesel production. Biotechnology for Biofuels, 5(1), 13.

13. Milchert, E., Goc, W., Lewandowski, G., \& Myszkowski, J. (1995). Dehydrochlorination of glicerol dichlorohydrin to epichlorohydrin. Chemical Papers, 49(3), 133-136.

14. Kot, A. M., Błażejak, S., Kurcz, A., Bryś, J., Gientka, I., Bzducha-Wróbel, A., Maliszewska, M., \& Reczek, L. (2017). Effect of initial $\mathrm{pH}$ of medium with potato wastewater and glycerol on protein, lipid and carotenoid biosynthesis by Rhodotorula glutinis. Electronic Journal of Biotechnology, 27, 25-31.

15. Kirk, P. L. (1950). Kjeldahl method for total nitrogen. Analytical Chemistry, 22(2), 354-358.

16. Miller, G. L. (1959). Use of dinitrosalicylic acid reagent for determination of reducing sugar. Analytical Chemistry, 31(3), 426-428.

17. Zhang, G., French, W. T., Hernandez, R., Alley, E., \& Paraschivescu, M. (2011). Effects of furfural and acetic acid on growth and lipid production from glucose and xylose by Rhodotorula glutinis. Biomass and Bioenergy, 35(1), 734-740.

18. Bligh, E. G., \& Dyer, W. J. (1959). A rapid method of total lipid extraction and purification. Canadian Journal of Biochemistry and Physiology, 37(1), 911-917.

19. Cutzu, R., Coi, A., Rosso, F., Bardi, L., Ciani, M., Budroni, M., Zara, G., Zara, S., \& Mannazzu, I. (2013). From crude glycerol to carotenoids by using a Rhodotorula glutinis mutant. World Journal of Microbiology and Biotechnology, 29(6), 1009-1017.

20. Saenge, C., Cherisilp, B., Suksaroge, T. T., \& Bourtoom, T. (2011). Potential use of oleaginous red yeast Rhodotorula glutinis for the bioconversion of crude glycerol from biodiesel plant to lipids and carotenoids. Process Biochemistry, 46(1), 210-218.

21. Quispe, C. A. G., Coronado, C. J. R., \& Carvalho, J. A. (2013). Glycerol: production, consumption, prices, characterization and new trends in combustion. Renewable and Sustainable Energy Reviews, 27, 475-493.

22. Manowattana, A., Seesuriyachan, P., Techapun, C., \& Chaiyaso, T. (2012). Optimization of carotenoids production by red yeast Sporobolomyces pararoseus TISTR 5213 using waste glycerol as a sole carbon source. KKU Research Journal, 17(4), 607-621.

23. Lubiewski, Z., Śmigielska, H., Lewandowicz, G., \& Balcerek, W. (2006). Charakterystyka odcieku po koagulacji białka pozyskiwanego w toku kampanii krochmalniczej. Zeszyty Problemowe Postępów Nauk Rolniczych, 511, 617-626.

24. Rozporządzenie Ministra Środowiska z dnia 18 listopada 2014 r. w sprawie warunków, jakie należy spełnić przy wprowadzaniu ścieków do wód lub do ziemi, oraz w sprawie substancji szczególnie szkodliwych dla środowiska wodnego. Dz. U. 2014 poz. 1800.

25. Braunwald, T., Schawemmlein, L., Graeff-Hönninger, S., Franch, W., Hernandez, R., Holmes, W., \& Claupein, W. (2013). Effect of different C/N ratios on carotenoid and lipid production by Rhodotorula glutinis. Applied Microbiology and Biotechnology, 97(14), 6581-6588.

26. Somashekar, D., \& Joseph, R. (2000). Inverse relationship between carotenoid and lipid formation in Rhodotorula gracilis according to the $\mathrm{C} / \mathrm{N}$ ratio of the growth medium. World Journal of Microbiology and Biotechnology, 16(5), 491-493.

27. Szymanowska-Powałowska, D. (2015). The effect of high concentrations of glycerol on the growth, metabolism and adaptation capacity of Clostridium butyricum DSP1. Electronic Journal of Biotechnology, 18(2), 128-133.

28. Bzducha-Wróbel, A., Błażejak, S., Molenda, M., \& Reczek, L. (2015). Biosynthesis of $\beta(1,3) /(1,6)$-glucans of cell wall of the yeast Candida utilis ATCC 9950 strains in the culture media supplemented with deproteinated potato juice water and glycerol. European Food Research and Technology, 240(5), 1023-1034. 
29. Sochocka, M., \& Boratyński ,J. (2011). Osmoregulacja - ważny parametr rozwoju bakterii. Postępy Higieny i Medycyny Doświadczalnej, 65, 714-724.

30. Fiedurek, J., \& Trytek, M. (2016). Wpływ stresu kwasowego i osmotycznego na wytwarzanie metabolitów przy użyciu mikroorganizmów. Postęy Mikrobiologii, 55(2), 195-204.

31. Cui, X., \& Ellison, M. (2012). Effects of biodiesel waste glycerol on the growth characteristics of Pichia pastoris genetically modified to produce spidroin. International Journal of ChemTech Research, 4(2), 713-719.

32. Easterling, E. R., French, W. T., Hernandez, R., \& Licha, M. (2009). The effect of glycerol as a sole and secondary substrate on the growth and fatty acid composition of Rhodotorula glutinis. Bioresource Technology, 100(1), 356-361.

33. Karamerou, E. E., Theodoropoulos, C., \& Webb, C. (2016). A biorefinery approach to microbial oil production from glycerol by Rhodotorula glutinis. Biomass and Bioenergy, 89, 113-122.

34. Murthy, U. M. N., \& Sun, W. Q. (2000). Protein modification by Amadori and Maillard reactions during seed storage: roles of sugar hydrolysis and lipid peroxidation. Journal of Experimental Botany, 51(348), 1221-1228.

35. Lund, M. N., \& Ray, C. A. (2017). Control of Maillard reactions in foods: strategies and chemical mechanisms. Journal of Agricultural and Food Chemistry, 65(23), 4537-4552.

36. Fell, J.W., \& Statzell-Tallman, A. (1998). "Rhodotorula" Harison. In: The yeast, a taxonomic study (red. Kurtzman, C. P., \& Fell, J. W.). Elsevier, Amsterdam, 800-827.

37. Berg, J. M., Tymoczko, J. L., Gatto, G., \& Stryer, L. (2015). Biochemistry (eight edition). W.H.Freeman \& Co Ltd.

38. Gientka, I., Kieliszek, M., Jermacz, K., \& Błażejak, S. (2017). Identification and characterization of oleaginous yeast isolated from kefir and its ability to accumulate intracellular fats in deproteinated potato wastewater with different carbon sources. BioMed Research International, 6061042-6061019.

39. Krzyściak, P., Halska, A., \& Macura, A. B. (2007). Występowanie i chorobotwórczość grzybów Rhodotorula spp. Postepy Mikrobiologii, 46(4), 291-300.

40. Casado, C., González, A., Platara, M., Ruiz, A., \& Ariño, J. (2011). The role of the protein kinase a pathway in the response to alkaline $\mathrm{pH}$ stress in yeast. Biochemical Journal, 438(3), 523-533.

41. Serra-Cardona, A., Canadell, D., \& Ariño, J. (2015). Coordinate responses to alkaline pH stress in budding yeast. Microbial Cell, 2(6), 182-196.

42. Ratledge, C. (1982). Microbial oils and fats: an assessment of their commercial potential. Progress in Industrial Microbiology, 16, 119-206.

43. Qin, L., Liu, L., Zeng, A. P., \& Wei, D. (2017). From low-cost substrates to single cell oils synthesized by oleaginous yeasts. Bioresource Technology, 245, 1507-1519.

44. Jiru, T. M., Groenewald, M., Pohl, C., Steyn, L., Kiggundu, N., \& Abate, D. (2017). Optimization of cultivation conditions for biotechnological production of lipid by Rhodotorula kratochvilovae (syn. Rhodosporidium kratochvilovae) SY89 for biodiesel preparation. 3 Biotech, 7(2), 145.

45. Rossi, M., Amaretti, A., Raimondi, S., \& Leonardi, A. (2011). Getting lipids for biodiesel production from oleaginous fungi. In M. Stoytcheva \& G. Montero (Eds.), Biodiesel feedstocks and processing technologies (pp. 71-92). Rijeka: InTech.

46. Orsavova, J., Misurcova, L., Ambrozova, J. V., Vicha, R., \& Mlcek, J. (2015). Fatty acids composition of vegetable oils and its contribution to dietary energy intake and dependence of cardiovascular mortality on dietary intake of fatty acids. International Journal of Molecular Sciences, 16(6), 12871-12890.

47. El-Banna, A. A. E. R., El-Razek, A. M. A., \& El-Mahdy, A. R. (2012). Isolation, identification and screening of carotenoid-producing strains of Rhodotorula glutinis. Food and Nutrition Sciences, 3(5), 627-633.

48. Razavi, S. H., Seyed, M. M., Hassan, M. Y., \& Marc, I. (2007). Fatty acid and carotenoid production by Sporobolomyces ruberrimus when using technical glycerol and ammonium sulfate. Journal of Microbiology and Biotechnology, 17(10), 1591-1597.

49. El-Banna, A. A., El-Razek, A. A. M., \& El-Mahdy, A. R. (2012). Some factors affecting the production of carotenoids by Rhodotorula glutinis var. glutinis. Food and Nutrition Sciences, 3(1), 64-71.

50. Reynders, M. B., Rawlings, D. E., \& Harrison, S. T. L. (1997). Demonstration of the Crabtree effect in Phaffia rhodozyma during continuous and fedbatch cultivation. Biotechnology Letters, 19(6), 549-552.

51. Yuan, S. L., \& Jian, Y. W. (2006). Optimization of cell growth and carotenoid production of Xanthophyllomyces dendrorhous through statistic experiment design. Biochemical Engineering Journal, 36(2), 182-189.

52. Bura, R., Vajzovic, A., \& Doty, S. L. (2012). Novel endophytic yeast Rhodotorula mucilaginosa strain PTD3 I: production of xylitol and ethanol. Journal of Industrial Microbiology \& Biotechnology, 39(7), 1003-1011.

53. Buzzini, P., \& Martini, A. (1999). Production of carotenoids by strains of Rhodotorula glutinis cultured in raw materials of agro-industrial origin. Bioresource Technology, 71, 41-44.

Publisher's Note Springer Nature remains neutral with regard to jurisdictional claims in published maps and institutional affiliations. 